\title{
Pelatihan dan Pembelajaran Metode Riset Aksi Partisipatoris Untuk Pemajuan Kebudayaan
}

\author{
P.M. Laksono \\ Pokja LAURA (Laboratorium Antropologi Untuk Riset dan Aksi) \\ Departemen Antropologi, Fakultas Ilmu Budaya, Universitas Gadjah Mada \\ Pos-el: laksono@ugm.ac.id
}

Tim Pengabdian kepada Masyarakat:

Citta Tresnati, Franciscus Apriwan, Ignatius Kendal, Kiki Koesuma Kristi, Olga Aurora

Nandiswara

\begin{abstract}
Sumba as one of the $3 T$ (Tertinggal/Disadvantaged, Terdepan/frontmost, Terluar/Outermost) regions in Indonesia has a crisis of acculturation in its development, where local customs and culture are no longer able to meet the demands of renewal of the development. Many scholars have conducted research and studies on Sumba and meanwhile, not a few Sumba people go outside Sumba to study and are expected to bring change to the land of Sumba. However, the crisis still occurs. Community Action Plans (CAP) are a way for the community to participate in the development. What is often questioned is the quality of the CAP itself which was conceived as a bottom-up effort in the development. Anthropology with its ethnographic methods and holistic participatory research methods can enrich the CAP to structure it to be more qualified by considering the principles of cultural advancement.

This training and learning of participatory action research methods offer a way to explore sociocultural capitals as the identity of the community to adjust to the changing times that occur through development. The Sumba student community who are studying in Yogyakarta and its surroundings are invited to play a role through the training and learning of the CAP-based culture promotion method so that they are expected to become pioneers in the development of Sumba culture through active community participation in Sumba. In addition, the Sumba community is expected to change as the times progress towards a more prosperous world without leaving their identity as Sumba people.
\end{abstract}

Keywords: Community Action Plans, Sumba Community, socio-cultural capitals

\begin{abstract}
Abstrak
Sumba sebagai salah satu daerah 3T (Tertinggal, Terdepan, Terluar) di Indonesia mengalami krisis akulturasi dalam pembangunan, yang adat dan kebudayaan setempatnya sudah tidak mampu lagi memenuhi tuntutan dari pembaharuan pada pembangunan yang dilaksanakan. Telah banyak akademisi yang mengangkat Sumba dalam riset dan kajian mereka. Sementara itu, tak sedikit pula orang Sumba yang pergi ke luar Sumba untuk menuntut ilmu dan diharapkan dapat membawa perubahan ke tanah Sumba. Namun demikian, krisis itu tetap terjadi. Sumba masih bergerak di tempat. Community Action Plan (CAP) atau rencana aksi komunitas menjadi salah satu cara bagi komunitas untuk berpartisipasi dalam pembangunan. Meskipun demikian, yang kerap menjadi pertanyaan adalah kualitas dari CAP yang digagas sebagai upaya bottom up dalam pembangunan itu. Antropologi dengan metode etnografi dan metode riset partisipatif yang holistik dapat memperkaya CAP yang disusun agar lebih berkualitas dengan mempertimbangkan asas pemajuan kebudayaan.
\end{abstract}


Pelatihan dan pembelajaran metode riset aksi partisipatoris ini dapat menawarkan sebuah cara menggali modal sosial budaya sebagai identitas dari komunitas untuk menyesuaikan diri dengan perubahan zaman yang terjadi melalui pembangunan. Komunitas mahasiswa Sumba yang sedang belajar di Yogyakarta dan sekitarnya diajak berperan lewat kegiatan pelatihan dan pembelajaran metode CAP berbasis pemajuan kebudayaan ini sehingga mereka diharapkan dapat menjadi pelopor dalam pengembangan kebudayaan Sumba melalui aksi partisipasi aktif komunitas di Sumba. Selain itu, komunitas Sumba diharapkan dapat berubah seiring perkembangan zaman menuju dunia yang lebih sejahtera tanpa meninggalkan identitas mereka sebagai orang Sumba.

Kata Kunci: metode riset aksi partisipatoris, komunitas mahasiswa Sumba, modal sosial budaya

\section{Pendahuluan}

Upaya pembangunan di Indonesia hingga saat ini masih dihadapkan pada beragam masalah. Masih banyak pertumbuhan ekonomi yang berbasis eksploitasi sumber daya alam yang memiliki konsekuensi buruk pada krisis sosial-budaya. Selain itu, tingkat pertumbuhan populasi yang melebihi kapasitas produktivitas bumi dan globalisasi menjadikan kehidupan sosial-ekonomi masyarakat menjadi lebih kompleks. Dalam usaha pembangunan dan menurunkan kemiskinan, Indonesia dihadapkan pada tantangan untuk melindungi lingkungan dan prospeknya untuk jangka panjang. Pembangunan berkelanjutan diperlukan sebagai upaya untuk memenuhi kebutuhan saat ini tanpa mengabaikan kebutuhan generasi mendatang. Kebudayaan menjadi salah satu modal terpenting bagi generasi mendatang dan bagi kerangka pembangunan berkelanjutan tersebut.

Dari perspektif antropologi, kebudayaan adalah keseluruhan sistem gagasan, tindakan, dan hasil karya manusia dalam rangka kehidupan masyarakat yang dijadikan milik diri manusia dengan belajar. Definisi dari Koentjaraningrat tersebut sangat populer, nyaris tanpa kritik, di kalangan intelektual di Indonesia. Pada kenyataannya, sejak akhir tahun 1970-an berkembang kritik yang serius, antara lain dari Parsudi Suparlan yang cenderung seperti Clifford Geertz (1992) yang membatasi pengertian kebudayaan hanya pada sistem gagasan yang berisi jaringan (pe)makna(an) (Laksono, 2015:10).

Koentjaraningrat (1959:139; 173-174) juga sejak lama memandang bahwa akulturasi atau perubahan kebudayaan di Indonesia itu sebagai proses ketika budayabudaya tempatan di Indonesia secara kreatif terlibat dalam mengonstruksi identitas (Indonesia). Di sana ada dialektika "dunia lama" dan "dunia baru" yang menghasilkan krisis serta keberagaman masyarakat (“jiwa baru” bangsa).

Laboratorium Antropologi Untuk Riset dan Aksi (LAURA) dari Departemen Antropologi Fakultas Ilmu Budaya UGM sebagai elemen perguruan tinggi yang harus mempunyai peranan penting dalam menggerakkan budaya ke arah kehidupan masa depan yang lebih berkelanjutan (more sustainably developed) dan melaksanakan pendidikan untuk pembangunan berkelanjutan dengan medium pendekatan budaya, telah melakukan upaya mengembangkan peningkatan kapasitas dan pendampingan pengetahuan komunitas masyarakat 3T (Terdepan, Terluar, dan Tertinggal) Indonesia melalui beragam program riset aksi dalam bidang pendidikan, nilai budaya, dan keadilan sosial-ekonomi. Dari riset aksi tersebut dipelajari adanya permasalahan keterpaduan 
antara proses pengembangan pembangunan di tingkat lokal 3T dengan isu arah pembangunan berkelanjutan nasional ke dalam praktik keseharian kehidupan budaya, sosial, dan ekonomi daerah mereka masing-masing.

Bersamaan dengan itu, beberapa waktu belakangan ini telah diterbitkan UndangUndang Nomor 5 Tahun 2017 tentang Pemajuan Kebudayaan yang menyebutkan bahwa pemerintah pusat menginginkan adanya gerakan pembangunan kebudayaan oleh pemerintah-pemerintah daerah sebagai investasi membangun masa depan dan peradaban bangsa. Gerakan tersebut dilakukan dengan langkah strategis melalui pelindungan, pengembangan, pemanfaatan, dan pembinaan guna mewujudkan masyarakat Indonesia yang berdaulat secara politik, berdikari secara ekonomi, dan berkepribadian. Namun demikian, langkah strategis ini belum disertai dengan metode atau instrumen (alat bantu) untuk pelaksanaan operasionalnya.

Oleh karena itu, dengan menjadikan pemajuan kebudayaan sebagai acuan, program Pengabdian kepada Masyarakat (PkM) LAURA ini diharapkan dapat mempertemukan dan memperkaya gagasan kebutuhan dari tingkat lokal 3T dengan isu arah pembangunan berkelanjutan tingkat pusat nasional, dengan melibatkan mahasiswa/generasi muda yang berasal dari wilayah-wilayah 3T tersebut. Berdasarkan Peraturan Presiden Nomor 131 Tahun 2015, empat kabupaten yang ada di Pulau Sumba terdaftar sebagai wilayah 3T (Tertinggal, Terdepan, dan Terluar) pada 2015-2019. Maka, dua puluh partisipan mahasiswa/generasi muda yang sedang menempuh kuliah pada berbagai perguruan tinggi di Yogyakarta terlibat aktif menjadi peserta dalam program PkM LAURA kali ini. Partisipan yang berproses aktif dalam waktu dua hari pelatihan ini, merupakan perwakilan empat wilayah kabupaten di Pulau Sumba, yaitu Sumba Timur, Sumba Tengah, Sumba Barat, dan Sumba Barat Daya. Pada akhir kegiatan pelatihan, partisipan diharapkan memiliki komitmen untuk menyebarluaskan dan membangun rencana aksi bagi wilayah masing-masing.

Lebih jauh lagi, hasil dari proses program ini adalah satu peta langkah awal dari kondisi kehidupan sosial-budaya di wilayah 3T, yang dapat menjadi salah satu pijakan bagi pendidikan tinggi dalam membangun program-program lanjutan atau rekomendasi untuk implementasi pembangunan berkelanjutan di wilayah-wilayah tersebut.

\section{Manfaat}

Manfaat dari kegiatan program ini antara lain sebagai berikut.

1. Adanya Modul Pelatihan Metode Riset Aksi Partisipatoris untuk pemajuan kebudayaan yang inklusif guna mendorong implementasi Tujuan Pembangunan Berkelanjutan dengan medium pemajuan budaya dalam komunitas-komunitas masyarakat 3T (Terdepan, Terluar, dan Tertinggal) Indonesia.

2. Komunitas-komunitas masyarakat $3 \mathrm{~T}$ memiliki dan mampu memakai serta mendayagunakan perangkat metode tersebut untuk mengentaskan masalahmasalah yang berkaitan dengan unsustainability menuju masa depan yang lebih berkelanjutan.

3. Terbangunnya atmosfer pendidikan, penelitian, dan pengabdian ilmu humaniora kepada komunitas-komunitas masyarakat 3T yang memperhatikan keberlanjutan generasi yang akan datang. 
4. Terbangunnya inisiatif awal gerakan kolaborasi untuk pemajuan kebudayaan di antara komunitas-komunitas masyarakat 3T.

\section{Skema Kegiatan}
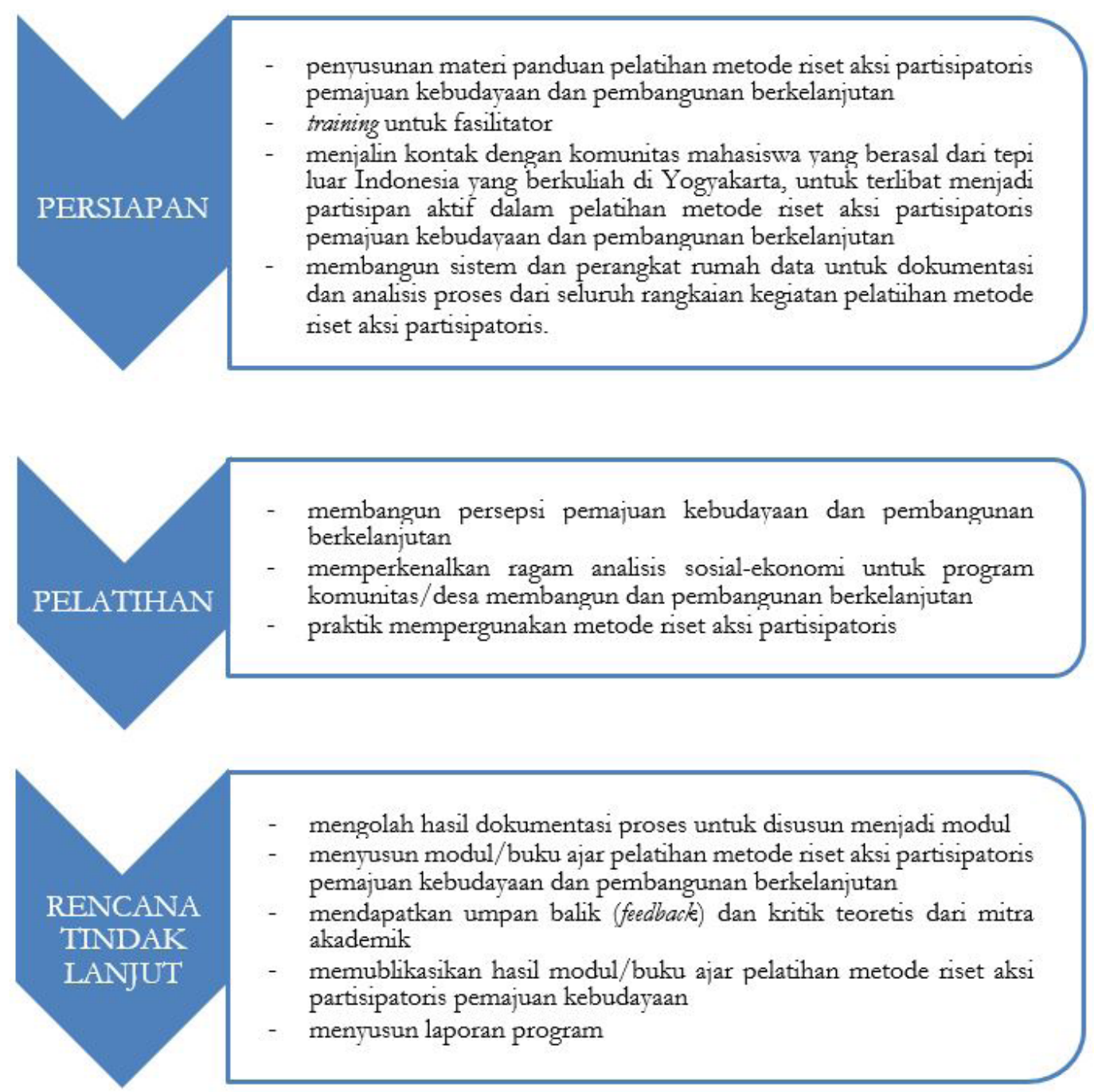

\section{Metode}

Metode yang dipergunakan dalam kegiatan pelatihan ini adalah metode Community Action Plan (CAP) dengan asas Trikon (Konsentrik, Konvergen, Kontinu) oleh Ki Hadjar Dewantara sebagai perspektif analisis. CAP memiliki arti penting dalam pembangunan nasional yang berkelanjutan. Pembangunan adalah sesuatu yang terencana dan juga melibatkan banyak pihak, terutama komunitas atau masyarakat yang menjadi sasaran pembangunan. Tidak dapat dimungkiri, ketika pembangunan dilaksanakan, komunitas sering menjadi objek perencanaan pembangunan, baik dari instansi pemerintah maupun dari lembaga lainnya. Hal ini merupakan bentuk sistem yang bersifat top-down. Kalaupun komunitas dilibatkan—akrab disebut sebagai sistem bottom-up-biasanya bentuk pelibatan itu hanya sebatas mendengarkan aspirasi dari komunitas. 
CAP dapat menjadi instrumen bagi komunitas untuk dapat berpartisipasi aktif dengan aksi nyata dalam pembangunan yang ada. Komunitas atau masyarakat mempunyai modal sosial-budaya yang kuat sebab mereka sendiri yang menjadi aktor utama dalam kehidupan sehari-hari. Kendati demikian, sering kali modal sosial-budaya komunitas itu terabaikan. Dengan CAP, modal sosial-budaya dari komunitas dapat dikenali kembali secara lebih terstruktur dan dapat menjadi dasar dalam partisipasi aktif komunitas dalam pembangunan.

CAP disusun atas dasar adanya kuasa dan keterampilan pada komunitas untuk mengembangkan program secara swakelola. Dengan demikian, warga bahkan dapat menyusun rencana dan mengembangkan sumber pendanaan secara mandiri. Dampaknya adalah warga dapat mengembangkan program sesuai dengan kebutuhan dan tidak didiktekan oleh pihak luar. CAP memberikan peta jalan yang relatif runtut agar komunitas benar-benar siap untuk merumuskan perencanaan secara partisipatif. CAP menggarisbawahi perlunya persiapan yang matang sehingga penyelenggaraan CAP bukan lagi berada di tangan lembaga luar komunitas, melainkan di tangan komunitas tersebut melalui kepanitiaan atau organisasi yang dibentuknya.

CAP juga menekankan perlunya komunitas memiliki informasi yang memadai dan akurat tentang permasalahan yang mereka hadapi, berkaitan dengan pembangunan berkelanjutan. CAP juga memberi peluang seluas-luasnya pada komunitas untuk dapat mengembangkan sendiri metode atau cara-cara dalam menggali informasi dari dan untuk komunitas. Dengan demikian, yang disebut 'pengetahuan' bukanlah sekadar informasi dari luar, melainkan lebih pada metodologi dalam memetakan pengalaman dan memproyeksikannya untuk tujuan yang diinginkan.

CAP dapat berfungsi memberikan panduan agar organisasi atau fasilitator lokal dapat melayani komunitas dalam memecahkan masalah berbasis pada sumber daya yang ada di tingkat lokal, mulai dari tingkat warga, komunitas, pemerintahan desa, hingga pemerintah daerah. Selain itu, metode CAP juga dapat memberikan panduan tentang cara memecahkan masalah, misalnya mendorong pemerintah daerah untuk meningkatkan responsivitasnya dengan melakukan advokasi kebijakan. Dengan demikian, CAP bukan hanya berisi daftar kebutuhan program dan penganggaran berbasis pada dana dari komunitas, melainkan juga menyediakan daftar kebutuhan program dan stakeholders yang diharapkan dapat memberikan dukungan dari tingkat komunitas, desa, kecamatan, atau SKPD.

Sementara itu, perspektif analisis yang digunakan dalam merumuskan CAP adalah asas Trikon yang disusun oleh Ki Hadjar Dewantara seeperti yang dipaparkan pada tabel 1.

\section{Undang-Undang No. 5 Tahun 2017 tentang Pemajuan Kebudayaan}

Beberapa pasal dari Undang-Undang Pemajuan Kebudayaan No. 5 Tahun 2017 yang menjadi acuan pokok dalam pelaksanaan kegiatan pelatihan ini adalah sebagai berikut.

\section{Pasal 5}

Objek pemajuan kebudayaan meliputi: a). tradisi lisan; b). manuskrip; c). adat istiadat; d). ritus; e). pengetahuan tradisional; f). teknologi tradisional; g). seni; h). bahasa; 1). permainan rakyat; dan j). olahraga tradisional. 
Tabel 1. Asas Trikon

\begin{tabular}{|c|c|c|c|}
\hline & Konvergen & Konsentrik & Kontinu \\
\hline $\begin{array}{l}\text { Kata atau } \\
\text { Frasa Kunci }\end{array}$ & siap berubah & $\begin{array}{l}\text { mengutamakan kearifan } \\
\text { lokal yang ada }\end{array}$ & $\begin{array}{l}\text { keberlanjutan/terus } \\
\text { menerus }\end{array}$ \\
\hline \multirow{4}{*}{ Indikator } & $\begin{array}{l}\text { bersikap terbuka } \\
\text { terhadap } \\
\text { perubahan dan } \\
\text { tantangan zaman }\end{array}$ & $\begin{array}{l}\text { menghargai nilai-nilai } \\
\text { adat }\end{array}$ & $\begin{array}{l}\text { tidak mudah } \\
\text { menyerah }\end{array}$ \\
\hline & $\begin{array}{l}\text { menerima inovasi } \\
\text { baru }\end{array}$ & $\begin{array}{l}\text { mengutamakan } \\
\text { pengembangan } \\
\text { pengetahuan dan } \\
\text { teknologi tradisional }\end{array}$ & $\begin{array}{l}\text { berorientasi } \\
\text { mengutamakan } \\
\text { ketersediaan sumber } \\
\text { daya di masa depan }\end{array}$ \\
\hline & $\begin{array}{l}\text { mampu berdaya } \\
\text { saing }\end{array}$ & $\begin{array}{l}\text { melibatkan sumber daya } \\
\text { lokal }\end{array}$ & pertumbuhan positif \\
\hline & $\begin{array}{l}\text { bersedia bekerja } \\
\text { sama dan } \\
\text { berjejaring dengan } \\
\text { pihak luar }\end{array}$ & $\begin{array}{l}\text { menjunjung } \\
\text { kepercayaan }\end{array}$ & $\begin{array}{l}\text { mengarah pada } \\
\text { kesejahteraan }\end{array}$ \\
\hline
\end{tabular}

\section{Pasal 10 Ayat 1}

Pokok pikiran kebudayaan daerah kabupaten/kota menjadi dasar penyusunan dan dimuat dalam Pokok Pikiran Kebudayaan Daerah provinsi.

\section{Pasal 11 Ayat 1}

Penyusunan pokok pikiran kebudayaan daerah kabupaten/kota dilakukan oleh Pemerintah Daerah dengan melibatkan masyarakat melalui para ahli yang memiliki kompetensi dan kredibilitas dalam Objek Pemajuan Kebudayaan di kabupaten/kota.

\section{Pasal 11 Ayat 2}

Pokok Pikiran Kebudayaan Daerah kabupaten/kota sebagaimana dimaksud pada ayat (1) berisi:

- identifikasi keadaan terkini dari perkembangan objek pemajuan kebudayaan di kabupaten/kota;

- identifikasi sumber daya manusia kebudayaan, lembaga kebudayaan, dan pranata kebudayaan di kabupaten/kota;

- identifikasi sarana dan prasarana kebudayaan di kabupaten/kota;

- identifikasi potensi masalah pemajuan kebudayaan; dan

- analisis dan rekomendasi untuk implementasi pemajuan kebudayaan di provinsi.

\section{Pasal 12 Ayat 1}

Penyusunan pokok pikiran kebudayaan daerah provinsi dilakukan oleh pemerintah daerah dengan melibatkan masyarakat melalui wakil para ahli yang terlibat dalam penyusunan pokok pikiran kebudayaan daerah kabupaten/kota dalam provinsi 
tersebut dan /atau pemangku kepentingan.

\section{Pasal 32 Ayat 1}

Pemerintah pusat, pemerintah daerah, dan/atau setiap orang dapat melakukan pemanfaatan objek pemajuan kebudayaan.

\section{Pasal 32 Ayat 2}

Pemanfaatan objek pemajuan kebudayaan dilakukan untuk:

- membangun karakter bangsa,

- meningkatkan ketahanan budaya,

- meningkatkan kesejahteraan masyarakat, dan

- meningkatkan peran aktif dan pengaruh Indonesia dalam hubungan internasional.

\section{Pasal 33 Ayat 1}

Pemanfaatan objek pemajuan kebudayaan untuk membangun karakter bangsa dan meningkatkan ketahanan budaya sebagaimana dimaksud dalam Pasal 32 ayat (2) huruf a dan huruf b dilakukan melalui:

- internalisasi nilai budaya

- inovasi

- peningkatan adaptasi menghadapi perubahan

- komunikasi lintas budaya

- kolaborasi antarbudaya.

Berdasarkan pasal-pasal di atas, upaya pemajuan kebudayaan sangat terbuka akan partisipasi komunitas atau masyarakat sebagai pelaku suatu kebudayaan tertentu selama berada di wilayah hukum Indonesia. Partisipasi komunitas inilah yang perlu dikelola dan CAP menjadi salah satu bentuk partisipasi yang dapat ditempuh oleh masyarakat dalam upaya pemajuan kebudayaan.

\section{Tahap Persiapan Pelatihan}

\section{Penyusunan Materi Panduan Pembelajaran Pelatihan}

Proses penyusunan materi ini melibatkan curah pemikiran dan pendapat dari LAURA, dua orang narasumber ahli terkait pengumpulan informasi awal, dan lima orang tim fasilitator, dengan menggarisbawahi perihal pengembangan dan peningkatan kapasitas serta pendampingan pengetahuan komunitas masyarakat 3T (Terdepan, Terluar, dan Tertinggal) Indonesia, berefleksi dari beragam pengalaman riset aksi lapangan yang telah dilakukan selama ini. Berdasarkan pengamatan terhadap permasalahan keterpaduan antara proses pembangunan dan keseharian kehidupan budaya di banyak tempat tersebut, kebutuhan keberdayaan komunitas dalam menentukan pemajuan kebudayaannya masing-masing menjadi hal yang utama.

Berpijak pada pandangan tersebut, kedua narasumber ahli dan lima orang fasilitator menyusun materi panduan pembelajaran yang berisi rangkaian sesi-sesi proses membangun rencana aksi komunitas (community action plan) pemajuan kebudayaan yang menggunakan asas Trikon sebagai perspektif analisisnya. Di 
samping itu, keseluruhan proses penyampaian materi pembelajaran pelatihan ini dikemas secara interaktif dan menyenangkan sehingga materi pelatihan menjadi sangat mudah diserap oleh partisipan.

\section{Training bagi Fasilitator Proses Pembelajaran Pelatihan}

Langkah selanjutnya adalah simulasi pelaksanaan sesi-sesi pelatihan bagi lima orang fasilitator untuk memastikan pembagian peran dan pengelolaan dinamika kelompok. Dengan demikian, proses antarsesi pelatihan dapat menjadi satu rangkaian yang utuh.

3. Menjalin Hubungan dan Menjaring Calon Partisipan

Setelah memastikan segala kesiapan teknis implementasi proses sesi-sesi pelatihan tersebut, langkah selanjutnya adalah membangun komunikasi dengan organisasiorganisasi mahasiswa yang berasal dari Indonesia bagian timur yang berada di Yogyakarta. Dari salah satu informan yang berasal dari organisasi mahasiswa daerah Nusa Tenggara Timur, LAURA dan tim fasilitator kemudian diperkenalkan dan dipertemukan dengan beberapa mahasiswa yang berasal dari Pulau Sumba.

Berdasarkan pertemuan dengan beberapa mahasiswa yang berasal dari Pulau Sumba ini, LAURA memperkenalkan diri dan menceritakan secara sekilas kerja-kerja LAURA di kawasan Indonesia bagian timur. Selanjutnya, LAURA menyampaikan maksud dan tujuan rencana kegiatan pelatihan serta pembelajaran metode riset aksi partisipatoris untuk pemajuan kebudayaan dalam waktu dekat ini, sekaligus manfaat yang dapat diperoleh dari hasil proses tersebut. Setelah saling berbagi perbincangan, pandangan, dan pemikiran, kemudian penawaran keterlibatan kegiatan oleh LAURA kepada perwakilan mahasiswa/generasi muda yang berasal dari Pulau Sumba itu disambut dengan baik. Mereka menyatakan komitmen dan bersepakat untuk terlibat aktif dalam proses pembelajaran pelatihan, serta dalam tempo 4 hari berikutnya akan memberikan kelengkapan daftar nama 20 calon partisipan mahasiswa/generasi muda kepada LAURA melalui tim fasilitator.

Yang menjadi bentuk komunikasi lanjutan dengan mereka adalah pemberitaan bahwa pelaksanaan kegiatan pelatihan dan pembelajaran metode riset aksi partisipatoris untuk pemajuan kebudayaan ini akan diselenggarakan pada 9-10 Juli 2018 dan bertempat di Gedung Soegondo, Fakultas Ilmu Budaya, Universitas Gadjah Mada.

\section{Tahap Pelaksanaan Pelatihan}

Pelatihan dilaksanakan selama dua hari, yakni 9-10 Juli 2018 dengan rincian kegiatan pelatihan sebagai berikut.

\section{Membangun Perspektif Pemajuan Kebudayaan dan Pembangunan Berkelanjutan}

Pelatihan pada hari pertama diawali dengan pengantar tentang antropologi, kebudayaan, krisis akulturasi, pemajuan kebudayaan, dan pembangunan berkelanjutan oleh Prof. Dr. P.M. Laksono, M.A. Peserta yang hadir memberikan beragam tanggapan berupa pertanyaan dan komentar atas apa yang sudah disampaikan oleh Prof. Laksono, terutama terkait isu kebudayaan yang ada di 
wilayah Pulau Sumba. Sesi pengantar yang dilanjutkan dengan diskusi ini secara umum membantu peserta memahami tesis dari pelatihan ini.

Pada hari pertama, sebelum peserta dibagi menjadi kelompok-kelompok kecil sesuai kabupaten asal, terdapat satu sesi pengantar mengenai UU Nomor 5 Tahun 2017 tentang Pemajuan Kebudayaan yang disampaikan oleh Franciscus Apriwan, salah satu fasilitator pelatihan. Peserta diperkenalkan pada objek-objek pemajuan kebudayaan menurut UU.

Sementara itu, topik pembangunan berkelanjutan diperdalam pada hari kedua. Pada hari kedua, salah seorang fasilitator, Kiki Koesuma Kristi, menyampaikan materi tentang community action plan (CAP) sebagai salah satu bentuk upaya untuk mewujudkan pembangunan berkelanjutan kepada peserta. Sesi ini juga menjadi sesi lanjutan dari pengantar UU Nomor 5 Tahun 2017 tentang Pemajuan Kebudayaan. CAP diperkenalkan sebagai salah satu langkah yang dapat ditempuh untuk berpartisipasi secara nyata dalam upaya pemajuan kebudayaan sesuai dengan amanat undang-undang.

\section{Memperkenalkan Ragam Analisis Sosial-Ekonomi untuk Program Komunitas/ Desa Membangun dan Pembangunan Berkelanjutan}

Substansi tentang ragam analisis sosial-ekonomi lebih banyak dilakukan di kelompokkelompok kecil. Peserta dibagi menjadi empat kelompok berdasarkan kabupaten asal. Hal ini bertujuan agar peserta dapat mengidentifikasi dan menganalisis kondisi sosial-ekonomi sesuai dengan konteks wilayahnya masing-masing sehingga rencana aksi yang nantinya akan disusun juga dapat lebih kontekstual.

Masing-masing kelompok didampingi oleh satu fasilitator yang bertugas memfasilitasi dan menemani peserta dalam proses pembelajaran selama dua hari pelatihan, serta satu pengamat yang bertugas mengamati dan membuat catatan proses dalam masing-masing kelompok. Kelompok Sumba Barat Daya didampingi oleh Kiki Koesuma Kristi sebagai fasilitator dan Pamerdyatmaja sebagai pengamat; kelompok Sumba Barat didampingi oleh Franciscus Apriwan sebagai fasilitator dan Selma Soraya Viollina sebagai pengamat; kelompok Sumba Tengah didampingi oleh Olga Aurora sebagai fasilitator dan Giza Feristya Sari sebagai pengamat; kelompok Sumba Timur didampingi oleh Citta Tresnati sebagai fasilitator dan Rico Takai Yama sebagai pengamat. Di samping itu, terdapat satu orang fasilitator penyelia, Ignasius Kendal, yang bertugas membantu keseluruhan proses dan mendukung tugas-tugas fasilitator di setiap kelompok.

Dalam kelompok kecil, peserta pelatihan diperkenalkan pada beberapa model analisis yang pernah diterapkan oleh LAURA dalam penelitian-penelitian terdahulunya, yakni model analisis holistik (melihat masalah sebagai satu kesatuan yang saling berhubungan satu sama lain) untuk merumuskan bagan persoalan, serta model analisis Trikon (konsentrik, konvergen, kontinu) oleh Ki Hadjar Dewantara untuk merumuskan solusi dari persoalan. Model-model analisis tersebut disinergikan dengan langkah-langkah identifikasi objek kebudayaan sesuai dengan amanat Pasal 11 Ayat 2 UU Nomor 5 Tahun 2017 tentang Pemajuan Kebudayaan, yakni dengan mengajak peserta untuk mengidentifikasi persoalan terkini objek kebudayaan di daerahnya, mengidentifikasi SDM/lembaga/pranata kebudayaan, 
mengidentifikasi sarana dan prasarana kebudayaan, serta mengidentifikasi potensi masalah objek pemajuan kebudayaan. Proses pembelajaran dilalui peserta dengan banyak melakukan diskusi dan praktik pemetaan, dengan media kertas plano, metaplan, dan alat tulis. Dari setiap sesi, peserta setidaknya menghasilkan satu buah plano yang merangkum hasil diskusi mereka terkait materi yang disampaikan.

\section{Praktik Mempergunakan Metode Riset Aksi Partisipatoris}

Pada hari kedua, peserta mempergunakan metode riset aksi partisipatoris lewat kegiatan menyusun CAP, sebagai bentuk solusi dari persoalan objek pemajuan kebudayaan yang sebelumnya telah mereka analisis. Peserta dalam kelompok kecil berdiskusi menentukan judul kegiatan, bentuk kegiatan, tujuan, sasaran, lokasi, indikator jangka panjang dan pendek, waktu, mitra, dan kebutuhan. Setelah rencana aksi CAP siap, masing-masing kelompok mempresentasikan hasil kerja mereka di kelas besar.

\section{Hasil Proses Pelaksanaan Pelatihan}

Hasil proses pelaksanaan pelatihan secara umum dapat dilihat dari dinamika peserta dalam kelompok kecil dan sesi-sesi presentasi oleh peserta pelatihan dalam kelas besar. Dalam kelompok kecil, para peserta cukup aktif menyampaikan gagasan dan pengalamannya terkait objek-objek kebudayaan yang ada di daerahnya dalam sesi-sesi diskusi dan pemetaan masalah. Di samping itu, para peserta juga tampak antusias dengan metode-metode serta istilah-istilah yang diperkenalkan oleh fasilitator. Bahkan, para peserta masih terus membicarakan metode dan istilah baru yang mereka dapatkan pada sesi istirahat.

Secara umum, peserta dapat mengikuti sesi-sesi diskusi dan pemetaan masalah dengan baik dan aktif meskipun terdapat beberapa hal yang membuat peserta mengalami kesulitan, salah satunya adalah pemahaman tentang klasifikasi objek-objek pemajuan kebudayaan. Selain itu, sebagian besar peserta juga mengalami kesulitan dalam membicarakan persoalan kebudayaan Sumba. Dalam hal ini peran fasilitator menjadi cukup penting. Fasilitator harus dapat menyusun strategi dalam merangsang peserta untuk mengeksplorasi topik terkait objek pemajuan kebudayaan yang terkadang dianggap cukup sensitif dan mengarahkan peserta agar tetap fokus pada topik pembicaraan tentang upaya pemajuan kebudayaan. Hal ini selanjutnya teruji pada sesi perencanaan CAP. Peserta di setiap kelompok berhasil merencanakan bersama setidaknya satu bentuk aksi yang relevan dengan masalah objek pemajuan kebudayaan yang telah mereka identifikasi pada sesi-sesi sebelumnya. Artinya, peserta di setiap kelompok mampu berdiskusi untuk merumuskan persoalan, menemukan solusi, dan membuat perencanaan aksi.

Dalam pelatihan ini, terdapat dua sesi presentasi hasil proses peserta kelompok. Sesi yang pertama adalah presentasi hasil identifikasi dan analisis masalah, sedangkan sesi yang kedua, di akhir pelatihan, adalah presentasi hasil perencanaan aksi CAP. Sesi presentasi hasil identifikasi dan analisis masalah dilakukan pada awal hari kedua. Masing-masing kelompok, diwakili oleh satu orang, mempresentasikan hasil diskusi mereka tentang objek kebudayaan yang mereka pilih serta masalah yang mereka temukan terkait objek kebudayaan tersebut. Kelompok yang pertama melakukan presentasi adalah kelompok Sumba Timur, yang diwakili oleh Ujho Piranyawa. Kelompok Sumba Timur 
mengangkat isu peran wunang dalam upacara kawin-mawin di Sumba Timur saat ini. Selanjutnya, kelompok Sumba Tengah mempresentasikan hasil diskusi mereka. Diwakili oleh Egi, kelompok Sumba Tengah mengetengahkan tema adat istiadat dan bahasa. Kelompok ketiga adalah kelompok Sumba Barat yang diwakili oleh Fajar Sumbawanto dan Okta Modo. Kelompok ini mempresentasikan hasil diskusi mereka tentang tradisi wulla podu di daerah tempat tinggal mereka. Kelompok terakhir yang mempresentasikan hasil diskusinya adalah kelompok Sumba Barat Daya, yang diwakili oleh Jemy U.P.B.Y Mahemba. Pada kesempatan tersebut, kelompok Sumba Barat Daya memaparkan kondisi terkini dari berbagai ritus yang ada di Sumba Barat Daya dan tantangan-tantangan yang muncul dalam upaya pelestarian ritus-ritus tersebut.

Pada sesi terakhir presentasi, masing-masing kelompok berkesempatan mempresentasikan hasil diskusi perencanaan aksi CAP sebagai bentuk upaya pemajuan objek kebudayaan yang telah mereka identifikasi pada sesi-sesi sebelumnya. Kelompok Sumba Barat Daya merencanakan aksi berupa penyusunan kurikulum berbasis Sumba, dengan langkah-langkah antara lain: membentuk tim, melakukan diskusi terpumpun, merumuskan kesepakatan bersama, audiensi dengan pemangku kebijakan, mengusulkan Raperda, dan melakukan monitoring serta evaluasi. Sementara itu, rencana aksi kelompok Sumba Barat juga mengusulkan pembentukan kurikulum yang sesuai dengan kebudayaan lokal, yang melibatkan elemen pemerintah, masyarakat, anak muda, guru, seniman, ketua adat, dan pelajar. Kelompok Sumba Tengah menyusun rencana aksi berupa edukasi tentang bahasa adat lewat pendidikan dan pendokumentasian serta penerbitan kamus bahasa adat. Para peserta dari Sumba Timur merancang aksi berupa kegiatan peningkatan kapasitas wunang dan kegiatan diskusi, yang rencananya akan mempertemukan para wunang saat ini dengan anak-anak muda Sumba sebagai calon-calon wunang.

Sementara itu, dari sesi evaluasi dan penyampaian kesan pesan, baik pada hari pertama maupun kedua, mayoritas peserta mengapresiasi kegiatan pelatihan dan pembelajaran ini. Salah satu alasannya adalah materi tentang pemajuan kebudayaan dan metode riset aksi partisipatoris merupakan hal yang baru bagi mereka. Selain itu, para peserta juga mengungkapkan bahwa kegiatan pelatihan ini menjadi ruang yang baik bagi mereka untuk berbagi dan mendiskusikan tema kebudayaan dengan temanteman peserta lainnya, serta dengan LAURA sebagai penyelenggara.

\section{Rekomendasi dan Rencana Tindak Lanjut}

Dari hasil evaluasi tahap persiapan hingga pelaksanaan kegiatan yang dilakukan oleh LAURA bersama tim fasilitator serta tim pengamat, terdapat beberapa hal yang menjadi rekomendasi jika kegiatan serupa akan diadakan kembali pada waktu yang akan datang. Pertama, pemahaman tiap peserta terkait objek-objek dalam pelatihan perlu dipastikan sebelum peserta memulai proses pembelajaran, dan dapat dilakukan melalui sesi pengantar yang lebih mendalam. Berdasarkan evaluasi, objek-objek yang telah dirancang untuk kegiatan pelatihan ini terlalu banyak jika diselesaikan dalam satu hari saja sehingga waktu yang dialokasikan untuk tiap sesi pengantar kurang mencukupi. Oleh karena itu, pada tahap persiapan, tim penyusun modul dan tim fasilitator perlu mempertimbangkan bobot materi serta waktu ideal yang dibutuhkan agar materi pembelajaran dapat diserap dengan lebih baik oleh peserta. Kedua, diperlukan aktivitas monitoring untuk memastikan tercapainya indikator keberhasilan jangka menengah dan panjang dari pelatihan ini. 
Sementara itu, rencana tindak lanjut utama dari kegiatan ini adalah menyusun modul pembelajaran riset aksi partisipatoris untuk pemajuan kebudayaan yang lebih baik, dengan mengolah hasil dokumentasi proses kegiatan pelatihan dan pembelajaran ini. Di samping itu, modul yang disusun ini diharapkan dapat memperoleh umpan balik dan kritik teoretis dari mitra-mitra akademik sebelum dipublikasikan agar hasilnya dapat lebih optimal.

\section{Penutup}

Program Pengabdian kepada Masyarakat yang ditujukan kepada komunitas mahasiswa Sumba yang tengah belajar di Yogyakarta dan sekitarnya disambut dengan penuh antusias oleh peserta. Pengetahuan tentang Community Action Plan (CAP) yang berbasis pemajuan kebudayaan menjadi ilmu yang baru bagi mereka. Dengan mengenal CAP berbasis pemajuan kebudayaan ini, para mahasiswa Sumba diharapkan dapat menggerakkan aksi komunitas di Sumba untuk menuju kesejahteraan ketika mereka kembali ke daerahnya. Diharapkan pula agar program Pengabdian kepada Masyarakat ini tidak berhenti pada tahap pengenalan CAP saja. Pada tahap berikutnya diharapkan adanya upaya praktik CAP secara nyata berdasarkan etnografi yang partisipatif hingga mengawal pelaksanaan CAP yang berbasis pemajuan kebudayaan, khususnya untuk daerah Sumba. Selain itu, kegiatan ini dapat menjadi bahan refleksi bagi keilmuan Antropologi dalam mengembangkan teori berbasis riset yang lebih partisipatif dan juga aplikatif.

\section{Referensi}

Dewantara, Ki Hadjar. 1994. Bagian Kedua: Kebudayaan. Yogyakarta: Majelis Luhur Persatuan Taman Siswa.

Geertz, Clifford. 1992. Tafsir Kebudayaan (terj). Yogyakarta: Penerbit Kanisius.

Koentjaraningrat. 1959. Metode2 Anthropologi dalam Penjelidikan2 Masjarakat dan Kebudajaan di Indonesia. Djakarta: Penerbitan Universitas.

1980. Beberapa Pokok Antropologi Sosial. Jakarta: Penerbit Dian Rakyat. 1985. Pengantar Ilmu Antropologi. Jakarta: PT Rineka Cipta.

Laksono, P.M. 2009. "Peta Jalan Antropologi Indonesia Abad Dua Puluh Satu: Memahami Invisibilitas (Budaya) di Era Globalisasi Kapital”, Pidato Pengukuhan Jabatan Guru Besar pada Fakultas Ilmu Budaya UGM, diucapkan di depan rapat terbuka Majelis Guru Besar UGM, 27 Oktober 2009 di Yogyakarta.

. 2014. "Pendidikan dan Pengelolaan Kebudayaan" dalam Teori, Etnografi, dan Refleksi. Heddy Shri Ahimsa-Putra (ed.). Yogyakarta: Jurusan Antropologi Fakultas Ilmu Budaya dan Pintal.

Laksono, P.M. dkk. 2015. Antropologi Pendidikan, Aneh: Biasanya Tidak Apa-Apa. Yogyakarta: Jurusan Antropologi Fakultas Ilmu Budaya Universitas Gadjah Mada dan Kepel Press.

Tim LAURA (Laboratorium Antropologi Untuk Riset dan Aksi) FIB UGM. 2013. Modul Community Action Plan (CAP) Untuk Pendidikan Berkualitas di Nusa Tenggara Timur.

Undang-Undang Republik Indonesia Nomor 5 Tahun 2017 tentang Pemajuan Kebudayaan. 